\title{
TOURIST DEVELOPMENT AND WASTEWATER TREATMENT IN THE SPANISH MEDITERRANEAN COAST: THE COSTA BRAVA CASE STUDY
}

\author{
ARIADNA GABARDA-MALLORQUÍ, ROSA M. FRAGUELL, DAVID PAVÓN \& ANNA RIBAS \\ Department of Geography and Institute of Environment, University of Girona, Spain.
}

\begin{abstract}
The Costa Brava (Girona, Spain) is one of the pioneering regions along the Spanish Mediterranean coast in terms of wastewater treatment. Since the 1950s, the water quality in swimming areas has been affected by the ongoing tourist development. However, at the same time, this issue has motivated the implementation of wastewater treatment systems that, otherwise, would have been delayed. With that mission, the Costa Brava Consortium (CCB) was created in 1971. The CCB is a public institution formed by all the municipalities along the coast of Girona, the head of Girona province and the watershed authority (formerly called the Eastern Pyrenees Hydrographical Confederation). Taking a conceptual approach derived from the Political Ecology of Tourism, the aim of this study is to explore the close relationship among the tourism boom, the economic and technologic investments related to wastewater management, and the improvement of environmental quality of the Costa Brava swimming areas.

We believe that the tourist sector has forced public administrations to minimize the environmental impact derived from tourist activities. In fact, wastewater treatment has contributed to achieve improved and optimal swimming conditions in beaches, the most valuable resource for sun and sand tourist sector. The increasingly strict environmental regulations issued at European level have an important role in the discursive legitimation of high public expenses. Nevertheless, water-related management costs have been progressively financed by tax-payers, under pretexts of economic crisis or limited public budget. In addition, private capital is considered as the only way to maintain present infrastructures and to invest in new ones.
\end{abstract}

Keywords: Costa Brava, Spain, tourism, wastewater management, water governance.

\section{INTRODUCTION}

In general terms, most of the research and studies conducted from a Political Ecology approach, emphasize environmental deterioration caused by global processes [1] related to global environmental change driving forces [2] as the construction of water infrastructures [3], the water quality and quantity impact caused by economic and demographic growth [4] or the tourist boom [5]. This last gives cause for complex and interrelated changes to the economy, the culture, the environment and the policies [6]. Certainly, natural resources being used by tourist industry may have different impacts. Thus, the Political Ecology of Tourism approach is a good conceptual framework in order to understand and define the relationship between environment and society [7]. Tourist sector is known as a big water consumer [5] because tourists not only consume water for personal uses, but they consume it through numerous leisure activities in which water use is required [8]. However, the more water is used, the more wastewater is produced. In that sense, wastewater must be treated in order to 
reduce and minimize its environmental impact [9]. In fact, discharging untreated wastewater into aquatic and/or marine ecosystems is one of the main environmental threats and could result in the pollution of valuable water resources [1].

Wastewater treatment systems are critical to guarantee environmental quality of coastal regions and require an actual political commitment by public administration through adequate investment. In recent years, the European framework directives have legitimized these large economic investments - always to promote a sustainable development - because all the States Members have to comply with the legislation. Thus, the Water Framework Directive (WFD) (2000/60/CE), approved by the European Parliament in 2000, is the starting point for an integrated water resources management and the improvement of aquatic and marine ecosystems. Due to the WFD, all the European states should adopt the proper mechanisms to achieve the main European Union principles. The environmental improvement of water bodies must go through the management of wastewater treatment systems funded by public administration.

Taking a conceptual approach derived from the Political Ecology of Tourism, the aim of this study is to explore the close relationship among tourism boom, economic and technological investments related to urban wastewater management and the improvement of environmental quality of the Costa Brava swimming areas. This study is structured as follows. Firstly, we present the study area, emphasizing the main points related to tourism sector. Secondly, through a retrospective analysis, we explain the main synergies and relationships between tourist development and urban wastewater treatment management. Finally, we present the conclusions, focusing on which trends have been followed in our case study and what are the scenarios related to wastewater management and governance.

\section{THE COSTA BRAVA}

The Costa Brava, located on the northeastern Iberian Peninsula coast, includes 22 coastal municipalities in Girona province (Northeast Catalonia, Spain), stretching from Portbou on the Catalan-French border, to Blanes, near the Barcelona province. The coast has a lineal length of $158 \mathrm{~km}$, but because of the presence of numerous gulfs and capes, this length rise to $274 \mathrm{~km}$. The 22 municipalities cover $662 \mathrm{~km}^{2}$, or $11 \%$ of the total area of Girona province. Dry, hot summers and mild winters, which are typical of coastal Mediterranean climates, characterize the Costa Brava. Despite interannual variability, most precipitation in this region occurs during the autumn.

Due to policies based on tourism-construction dualism, instead of a more commercial tourist accommodation, second-home urbanizations have become the main tourist resource offered in the Costa Brava (Fig. 1). As a consequence of these policies, nowadays three quarters of accommodation beds in the Costa Brava correspond to residential tourism.

According to the Occupation and Business Observatory, from October 2014 to September 2015 , the origin of foreign tourists was divided as follows: firstly, tourists coming from France (28.7\%), secondly those coming from the United Kingdom (10.7\%) and thirdly, Germany $(7.6 \%)$ [12]. The seasonality is still really pronounced and determined by the school holidays. High rates of summer occupancy with intense resource consumption - specially energy and water - and the low influx of visitors during the winter period, are two of the most relevant environmental and economic impacts in the region. Despite the potential climatic conditions for costal tourism, that could extend the peak season and promote the winter products campaigns, only some municipalities, as Lloret de Mar, have achieved an extended tourism season by offering different packages during low season. 


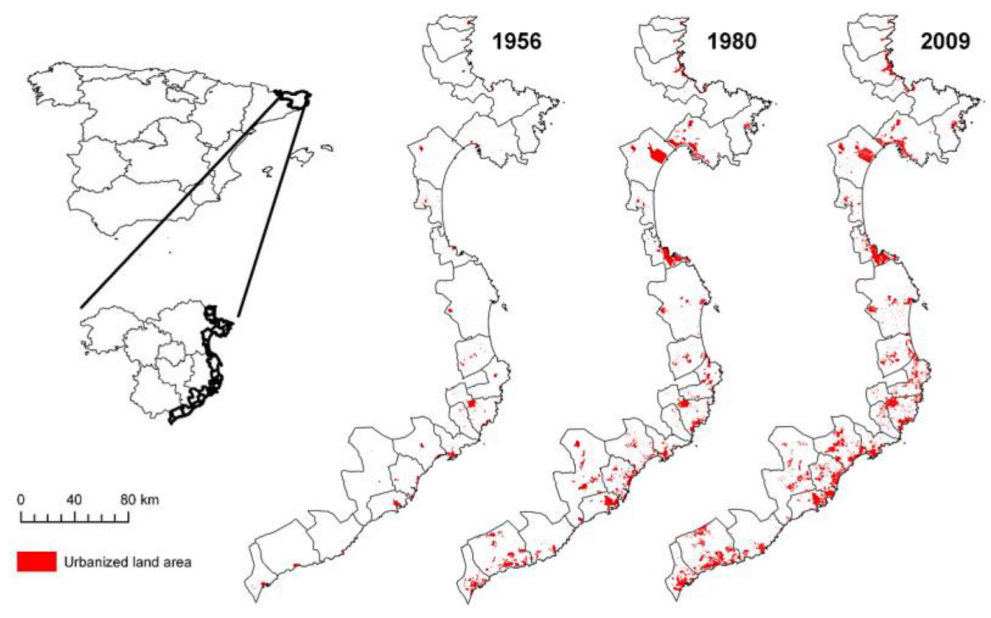

Figure 1: Evolution of urban areas in the Costa Brava, 1956, 1980 and 2009. Source: Compiled by the authors from data provided by Martí [10] and CREAF [11].

\section{TOURISM AND WASTEWATER TREATMENT IN THE COSTA BRAVA}

The tourist development on the region has caused new needs related to the use and consumption of natural resources and the management and treatment of wastewater. In that sense, and according to the goal of this study, the main synergies between tourist development and sewage treatment and purification in the Costa Brava during the XX century and the beginning of the XXI are analysed.

\subsection{Uncontrolled effluent discharge (the beginning of XX century-1980)}

Before the massive arrivals of tourists, at the beginning of the XX century, the Girona province coast was visited sporadically. The low tourists flow came to the Costa Brava to enjoy the sea, attracted also by the landscape singularity. These tourist 'pioneers' were part of the bourgeoisie and mainly came from the main cities located in a short distance to the Costa Brava. Gradually, first summer houses were built around the Costa Brava towns. Later, tourists from further away, formed by artists, writers and aristocrats, visited this coastal region. They started to build luxurious second homes. Usually these second homes were located on high and isolated places with great sea views. The tourism consolidation period began in the fifties. In this sense, the initial urban development process caused by tourist arrivals was easy to assimilate. However, as a consequence of the massive international tourist arrivals in the later decades, organized mainly by tour operators, urban growth was so disproportionate that soon the first environmental impacts were noticeable. Decision-makers with experience in urban strategy planning were appointed to deal with mass tourism issues, such as the lack of transport infrastructures in the Costa Brava. The construction of the Girona province airport, the AP7 highway to the French border, and the secondary road network solved the isolation of the coastal towns but lead to the consolidation of a tourist model excessively focused on the Costa Brava coastal area [13]. Certainly, regarding the number of tourist arrivals and hotels availability, during this period tourism in the Costa Brava would experience its peak. In fact, the provinces of Girona, Alicante and Malaga, the Balearic Islands and the Canary 
Islands, represented between $80 \%$ and $85 \%$ of all foreign overnight stays in Spain [14]. Increasing tourist demand caused substantial social, urban and economic changes along the coastline and two different tourist types coexisted during the sixties and the seventies: mass tourism, which was growing faster, and pre-Fordist tourism, which was surviving the fast changing conditions [15]. The Fordist tourism, a tourist model based on landscape homogeneity with high urban growth rates (425\% from 1956 to 1980) [10], would reach its highest during the sixties. In that sense, tourism consolidation in the Costa Brava caused severe environmental impacts, such as the wastewater generation and the overexploitation of water resources, among others. High water consumption, especially during summer months (high season), would imply the generation of large volumes of wastewater. Due to uncontrolled wastewater discharged into streams or directly to the sea, the aquatic and marine ecosystems were in risk of water pollution. The lack of an actual urban wastewater management threatened the tourist reputation of the Costa Brava. Interest in improving the quality of swimming areas on the Costa Brava materialized with the creation in 1971 of the Costa Brava Consortium (CCB), a key milestone in urban wastewater treatment management. Twenty-seven municipalities, the Head of Girona province and the watershed administrator (then called the Eastern Pyrenees Hydrographical Confederation (CHPO)) joined together with a main goal: build an efficient wastewater system required to cope with water pollution in swimming areas.

The CCB was created when first concerns arose about the quick and severe coastal transformation caused by the tourism. The publication of an especial issue in a regional journal in the summer of 1975 called 'Costa Brava Trial' (Judici a la Costa Brava, in catalan) would become the precedent of the First Costa Brava debate, hold at the end of 1976 [16]. It was aimed to discuss common concerns about the growing problems in the Costa Brava. The debate compiled all the communications presented and became the main principle for a more sustainable and rational development in the Costa Brava. One of the communications presented by the Commission of the Ter River Protection reported the lack of mechanisms to avoid the uncontrolled wastewater that was discharged into the Ter River and demanded measures to treat urban wastewater. Additionally, and some years later, the White Tourism Paper of Catalonia [17] coincided with the high level of pollution in rivers and streams because they 'were currently receiving effluents coming from important towns that arrive there without any treatment'.

The CCB was in charge of drafting the Wastewater Treatment Infrastructures Plan of the Costa Brava (1971-1975), a strategy program through which the first wastewater treatment plants and sewer systems were built in eight Costa Brava municipalities [18]. At the beginning of 1980, and only within the 9 years of CCB, 7 out of 22 municipalities of the Costa Brava would have a wastewater treatment system. The management was shared among three administration levels. The Spanish central government financed the 50\% of all the constructions reflected in the plan, while the CCB managed the funding for the $50 \%$ left to the municipalities. The CHPO was responsible for building the wastewater treatment plants. The operational costs were funded out of tax revenues charged to households, hotels and campsites connected to the sewer system.

3.2 The joint wastewater management and the environmental improvement of swimming areas (1980-1993)

During the eighties, and after the tourist boom, first evidences of crisis in the tourist sector started to emerge. Both number of tourist arrivals and the revenue per tourist were reduced 
and caused a decline in tourism development [19]. New competitive tourist destinations that were launched would make the Spanish tourist crisis effects more severe [20, 21]. This regression resulted in an obstacle to new beds offer and hotel sector obsolescence [14] due to a lack of tourist innovation and diversification. To deal with the tourist model stagnation, the Framework Plan for Spanish Tourism Competitiveness was developed in 1992 to update Spain's tourist policies and reorganize the sector focusing on the modernization of hotel industry. The realization of this plan through operative actions was focused on addressing the tourist sector to new markets targeting higher income tourists, and increase hotel industry competitive based on a quality improvement [21]. Thus, between 1992 and 1999, Costa Brava tourist sector was adapted to a major categorization: three- to five-star hotels gained market share at the expense of guesthouses and one- and two-star hotels. However, regarding water supply management, this tourist modernization led to an increase in the presence of gardens and swimming pools in Costa Brava hotel industry, two hotel services that requires large quantity of water to operate [22] and implied an important increase in water consumption.

During the eighties, a new institutional reform concerning water management in the Costa Brava, and especially wastewater management, was performed. With the passing of the Decree 350/1985, the Regional Government of Catalonia was granted competences with regards to wastewater management and jurisdictions were constituted. The CCB was the only administrator in charge of zone number 14, the Costa Brava. Moreover, construction of wastewater systems and their maintenance funding service was modified. The CCB started to raise taxes (the ITS tax) due to the need to defray the urban wastewater treatment costs. This new tax design would permit to lead the paradox related to the previous tax, which was paid only by those who treat urban wastewater (i.e. 'I am the one who protects the environment and also who have to pay a tax to cover the cost related to'). The tax was applied on the water bill of households, hotels and/or campsites, whether were connected to sewer systems or not [23]. In terms of planning, the CCB drafted and implemented the Costa Brava Wastewater Treatment Special Plan, an updated plan where different studies, projects and constructions related to urban wastewater treatment and their operational costs were included.

After numerous urban sewage treatment plants started operate in some Costa Brava municipalities (14 plants in 1990), the quality of swimming areas and beaches improved over time. In fact, this was the first goal regarding the CCB foundation, besides the water supply management that was also another important issue managed by the CCB. These wastewater treatment plants made possible the minimization of the pollution of Costa Brava's aquatic and marine ecosystems. In Catalonia, since 1984, seawater quality monitoring was implemented in line with the UE Seawater Directive 76/60/CEE. From the creation of the Environment General Manager of Catalonia Regional Government, the physicochemical testing of swimming areas water quality was included in the monitoring. Thus, during the summer high season since the 1990s until now, weekly water quality monitoring of the coastal swimming areas of Catalonia has been carried out. As an example, and thanks to the treatment of Costa Brava urban wastewater, the quality of some beaches has improved significantly.

\subsection{The recentralization of the wastewater treatment management and tourist planning} (1993-2008)

After a period of an anarchic tourist development, the need for planning and designing the Costa Brava tourism growth strategy was detected. For this purpose, in 1997 it was created 
the Sustainable Tourist Development Plan of Girona province, promoted by the Costa Brava Tourism Board. This plan identified hotel industry obsolescence in terms of infrastructure and service offer. It also raised concerns about the lack of investment to satisfy tourists' need or to access to new demand sectors. Although the plan diagnosis took into account economic, social and environmental issues of the tourism sector, water management was not addressed. In environmental terms, the plan aimed to achieve a 'well-balanced and organized tourist development in harmony with cultural and natural environment', but not find sustainable and fair water management solutions. Despite tourist crisis effects, second homes gained significance within tourist accommodation offer and in 1991 the $61 \%$ of all the homes in the Costa Brava were second residences. The evolution of residential tourism was so important that soon 'an actual holidays metropolitan area' was created [24].

At the beginning of the nineties, in Catalonia, and in terms of organization, wastewater treatment management was organized through two jurisdictions: the A zone, comprised by river basins within Catalonia; and the $\mathrm{B}$ zone, where the intercommunity watersheds were included. In 1993, Costa Brava region would be included in the A zone. Thus, the Costa Brava Wastewater Treatment Special Plan was combined with the Catalan Wastewater Treatment General Plan. After that, the Catalan Regional Government took charge of CCB role and the ITS tax management was revoked. This centralization process resulted in the fact that the Catalan Regional Government contributed to the funding of wastewater infrastructures development and maintenance [18]. During the nineties, 7 wastewater treatment plants were built and, including the pre-existing 15, all the Costa Brava municipalities had a wastewater treatment system.

Despite the signs of stagnation in the tourist model during the nineties, the 2000s were more favourable to boost tourism sector recover. At least during the first years, between 2001 and 2007, Costa Brava tourist arrivals rates increased by an annual average of $3.88 \%$. Thus, tourism has become during the 2000s in Catalan, and therefore of the Costa Brava, a key sector for the regional economy [25]. In 2005, tourism was one of the economic activities with major contribution to the Costa Brava GDP (16.17\%) which was higher than Catalan average GDP $(10.23 \%)$. Because of the economic dependency on tourism in the Costa Brava, the 2000s were an important milestone regarding tourist strategy planning. Thus, in 2002, the first Tourism Law was approved by the Catalan Regional Parliament. However, Catalonia would be the latest Spanish region to approve a law that regulates tourist activities. Moreover, it would be approved without a wide consensus in the Catalan Parliament, with a difference of only one vote [26]. Another important milestone related to Catalonia tourism management was the First Tourist Strategic Plan approved in 2005. This strategic plan was focused on the need to manage land and natural resource uses to tackle the environmental problems caused by tourist activities.

Undoubtedly, water planning and management received, during this period, different inputs that would force public administration to adapt to new directives and regulations. Certainly, the Water Framework Directive (WFD) approved in 2000 by the European Parliament became a new starting point for water resources management [15]. The creation of the Catalan Water Agency (ACA) as a main public administrator in charge of Catalan water management would become a key milestone to materialize the WFD principles. Among different policies, the ACA proposed and promoted the creation of a new water tax that would be applied in the water bills and aimed to cover operational costs related to wastewater treatment management. Despite the wastewater treatment management recentralization, the CCB was still the Costa Brava main administrator. One of the most important strategies developed towards a more sustainable water resources management in the Costa Brava has 


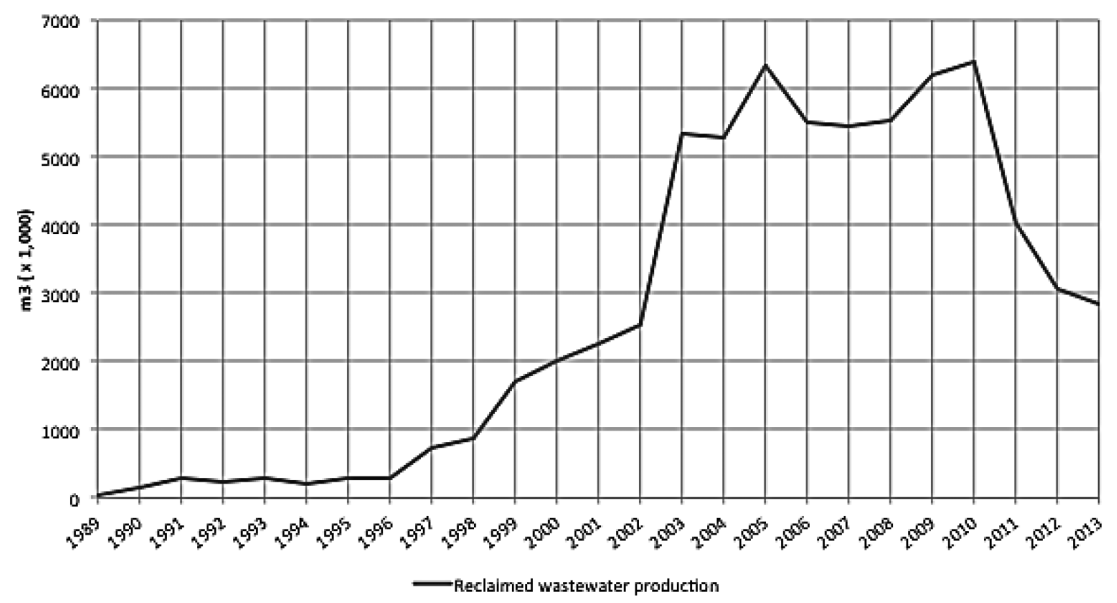

Figure 2: Reclaimed wastewater produced in the Costa Brava, 1989-2013. Source: Compiled by the authors from data provided by CCB.

been the decision to reuse reclaimed wastewater. From 1996 to 2015, $600 \mathrm{hm}^{3}$ of wastewater have been treated through wastewater treatment plants. The initiative to reuse this treated wastewater quantity has resulted in a new water resource used to irrigate public gardens, golf fields, aquifer recharge and non-potable municipal uses as public space cleaning. The quantity of reclaimed wastewater accumulated from 1989 to 2013 has reached the $67 \mathrm{hm}^{3}$ (see Fig. 2).

3.4 The public administration crisis and the first privatization processes related to water management (2008-2014)

The economic crisis that started in 2008 accelerated privatizations processes in services related to water management. In that context, public administration is living an adjustment in its funding and its action capacity, with strong measures to control the expenses and halt the deficit. In the Spanish context, according to the Spanish Association of Supply and Sanitation Public Operators (AEOPAS) [27], in 1996, 63\% of the population was supplied by public companies. In 2005, this percentage decreased to a $52 \%$ and, in 2010 , to a $47 \%$. The AEOPAS noticed that, by the end of 2015, a $57 \%$ of the population would be supplied by private companies. Privatization processes are being carried out without a desirable debate and are based on supposed public-private collaboration. Generally, they are focused on public-private joint venture where public administrator has the $51 \%$ of the shares but finally the real control is managed by the private partner through clauses that give them exclusive competences with regard to general management. Therefore, although local administrators receive the income related to management transfer, at the end it could lose its control over real water resources and, the private partner, might operate in secretive monopolistic conditions [28].

In Catalonia, according a study carried out by 'Water is Life' (Aigua és vida, in catalan) association in 2015 , it is thought that almost the $84 \%$ of the population in the region, that is 6.31 million inhabitants, were living in municipalities where water supply management was managed by private or semi-private companies. Only the $16 \%$ was managed by a public administrator [29]. In the Costa Brava municipalities, according the same source, only one of 
them had public management and in the other three the management was carried out by a public-private joint venture.

Regarding high level water supply system in the Costa Brava, in January 2010 a publicprivate joint venture, called ABASTEM, was established formed by the CCB, who had the $48 \%$ of the shares, and two private companies, Aqualia and Sorea, with the $52 \%$ of the rest, as a major private stockholder. This business structure is responsible for managing and guaranteeing water supply to the municipalities of the Costa Brava. This kind of mixt-based management started to operate 4 years after the creation, in 2006, of a similar business structure to manage high level wastewater treatment systems which until that date was under the administration of the CCB. Thus, with this purpose, the Mixt-based Water Company of the Costa Brava (EMACBSA) was created. In that case, the private partner owned the $66.6 \%$ of the shares [30].

At the same time, the ACA experienced a similar privatization process. The deficit coming from the difference between the water tax revenues and even higher expenses related to water infrastructure developments that the ACA is dealing with, has resulted in a severe indebtedness. The ACA has rescinded part of its public services and investments as well as part of its staff. As a consequence, the last privatization process has been appeared in 2012 with the tender for the contract to manage high level water supply system to five millions of people from the Metropolitan Area of Barcelona, previously operated by the public company TerLlobregat Water (ATLL). It was a polemical process carried out by the Catalan Regional Government that resulted in the privatization of water supply in favour of Acciona Company for a period of 50 years [31]. A year later, in 2013, the public-private joint venture Barcelona Water SA, who supplies water to an important number of municipalities of Barcelona Metropolitan Area, is created.

\section{DISCUSSION AND CONCLUSIONS}

This study has analysed how to understand the relations between tourist activities and their impact to water resources through an approach related to the Political Ecology of Tourism. This process allows to determine and identify which stakeholders are implied and what processes have configurated the existing hydrosocial cycle in tourist areas such as the Costa Brava. In fact, tourism has been the main factor that has motivated the environmental improvement through the development of wastewater systems, fact that has allowed the tourist development in the Costa Brava. The joint service management, such as urban wastewater treatment, is considered as one strategic method followed in order to achieve a high performance in terms of efficiency and equity [32]. The Costa Brava Consortium is an example of how a joint management allows overcoming territorial inequality by establishing a common project at regional level.

Due to the WFD approval, environmental concerns are part of the agenda in the communal legislative system. Thus, the strategic planning of the urban water cycle is placed on the top priority of the local water resources management. The compulsory European directives have legitimated the environmental discourse because all state members should implement the proper actions in order to guarantee a high environmental quality needed to encourage economic and social sustainable development. While wastewater management was based on design and plan the construction of infrastructures, the governance model achieved to provide the region with an efficient wastewater treatment system. Then, Costa Brava beaches and swimming areas quality, two of the most important tourist recources, improved significantly. However, system loses efficiency when the administrator is in charge of the infrastructure maintenance and operation. At this point, water management costs have been 
progressively charged to citizens through application of taxes and/or increases in water price. Then, the private capital inflow to public sanitation management companies is considered nowadays a way to maintain the existing infrastructures and to fund new ones if necessary.

From this point of view, the medium-term challenge would be the fact that mechanisms of public control ensure an equitable balance of the cost of environmental improvement among the sectors involved. The WFD sets the recovery of water services costs but it must include also those related to wastewater treatment. However, this issue requires being highly careful when the cost is transferred to all users. Moreover, it is fundamental to clarify the weight of each possible water concepts and their management and governance role: water understood as a natural resource with basic access or water as an object with which business and profit expectations are generated.

\section{REFERENCES}

[1] Stonich, S.C., Political ecology of tourism. Annals of Tourism Research, 25(1), pp. 25 54, 1988. http://dx.doi.org/10.1016/S0160-7383(97)00037-6

[2] Ajibade, I. \& McBean, G., Climate extremes and housing rights: a political ecology of impacts, early warning and adaptation constraints in Lagos slum communities. Geoforum, 55, pp. 76-86, 2014. http://dx.doi.org/10.1016/j.geoforum.2014.05.005

[3] Nüsser, M., Political ecology of large dams: a critical review. Petermanns Geographische Mitteilungen, 147(1), pp. 20-27, 2003.

[4] Tello, E. \& Ostos, J.R., Water consumption in Barcelona and its regional environmental imprint: a long-term history (1717-2008). Regional Environmental Change, 12, pp. 347-361, 2012. http://dx.doi.org/10.1007/s10113-011-0223-z

[5] Cole, S., A political ecology of water equity and tourism. Annals of Tourism Research, 39(2), pp. 1221-1241, 2012. http://dx.doi.org/10.1016/j.annals.2012.01.003

[6] Gössling, S. (ed.), Tourism and Development in Tropical Islands. Political Ecology Perspectives, Edward Elgar Publishing: Cheltenham, UK, 2003.

[7] Douglas, J.A., What's political ecology got to do with tourism? Tourism Geographies, 16(1), pp. 8-13, 2014. http://dx.doi.org/10.1080/14616688.2013.864324

[8] Gössling, S., Peeters, P., Hall, C.M., Ceron, J.-P., Dubois, G., Lehmann, L. V. \& Scott, D., Tourism and water use: supply, demand, and security. An international review. Tourism Management, 33, pp. 1-15, 2012. http://dx.doi.org/10.1016/j.tourman.2011.03.015

[9] Gladstone, W., Curley, B. \& Shokri, M.R., Environmental impacts of tourism in the Gulf and the Red Sea. Marine Pollution Bulletin, 72, pp. 375-388, 2013, available at http://doi.org/10.1016/j.marpolbul.2012.09.017.

[10] Martí, C., La transformació del paisatge litoral de la Costa Brava: Anàlisi de l'evolució (1956-2003), diagnosi de l'estat actual i prognosi de futur (unpublished doctoral dissertation), Universitat de Girona: Girona, 2005.

[11] CREAF, Mapa de cobertes del sòl de Catalunya v4, 2009, Retrieved from www.creaf. uab.cat $/$ mcsc.

[12] OEO (Occupation and Business Observatory), Demanda turística, Retrieved from http://observatoriempresaiocupacio.gencat.cat/ca/obs_ambits_tematics/obs_turisme/ 
[13] Llurdés, J.C., Els canvis en el sector turístic. Canvis socioambientals a l'Alt Empordà (1950-2000), eds. A. Ribas \& D. Saurí, Servei de Publicacions de la Universitat de Girona: Girona, 2002.

[14] Vasallo, I., Crisis y consolidación, 1972-1982. 50 años del turismo español: un análisis histórico y estructural, eds. F. Bayón Mariné, H. Marcos Valdueza, C. Vogeler Ruiz \& M.A. González de Souza, Centro de Estudios Ramón Areces: Madrid, 1999.

[15] Gabarda-Mallorquí, A. \& Ribas, A., Understanding reductions in water consumption in tourist areas: a case study of the Costa Brava, Spain. International Journal of Water Resources Management, 2016, (in press). http://dx.doi.org/10.1080/07900627.2016.1142861

[16] Aragó, N., El Debat Costa Brava, pas a pas. Retrieved from: https://dialnet.unirioja.es/ servlet/articulo?codigo $=769018$

[17] Miguelsanz, A., Llibre blanc del turisme a Catalunya, Generalitat de Catalunya, Departament de la Presidència: Barcelona, 1983.

[18] Serra, M., Sala, L. \& Mujeriego, R., Situación actual y avances recientes en la reutilización planificada en la Costa Brava, Retrieved from http://www.us.es/ciberico/ archivos_acrobat/sevilla1serra.pdf.

[19] Prat, J.M. \& Cànoves, G., Cultural tourism as a complementary offer in coastal destinations. the case of the Costa Brava (Spain). Investigaciones Geográficas, 79, pp. 119-135, 2012.

[20] Dekker, J.B. \& Hoekstra, B.D., ¿Un futuro para la Costa Brava? University of Groeningen: Netherlands, 1992.

[21] Llurdés, J. \& Blanco, A., La evolución del turismo en España. Estrategia y gestión del turismo en el municipio, eds. G. Priestley \& J. Llurdés, Servei de Publicacions de la Universitat Autònoma de Barcelona: Barcelona, 2007.

[22] Deyà Tortella, B. \& Tirado, D., Hotel water consumption at a seasonal mass tourist destination. The case of the island of Mallorca. Journal of Environmental Management, 92, pp. 2568-2579, 2011.

http://dx.doi.org/10.1016/j.jenvman.2011.05.024

[23] Serra, M., Les depuradores de la Costa Brava, un cas insòlit, 1987, Retrieved from http://www.revistadegirona.cat/recursos/1987/0120_042.pdf.

[24] Fraguell, R.M., Turisme residencial i territori: la segona residència a les comarques gironines, Publicacions de la Universitat Autònoma de Barcelona: Barcelona, 1994.

[25] Duro, J., Estimació del PIB turístic per Catalunya, marques i comarques 2005-2010, Universitat Rovira i Virgili: Tarragona, 2011.

[26] López, F., La gestión pública del turismo en Cataluña. Organización y política turística de la administración autonómica. Investigaciones Geográficas, 34, pp. 5-27, 2004. http://dx.doi.org/10.14198/INGEO2004.34.05

[27] AEOPAS, available at http://www.aeopas.org/.

[28] Babiano, L. \& Giménez, M., Retrieved from https://www.diagonalperiodico.net/ global/26637-agua-crisis-y-privatizacion.html.

[29] Garriga, J., Aigua, de l'aixeta privada a la pública. L'Econòmic, 4-10, p. 18, 2015.

[30] EMACBSA, available at http://www.aiguescb.com.

[31] March, H., La nova "guerra de l'aigua" a Barcelona: austeritat, deute i participació privada. Documents d'Anàlisi Geogràfica, 60(3), pp. 505-521, 2014.

[32] Hantke-Domas, M. \& Jouravlev, A., Lineamientos de politica pública para el sector de agua potable y saneamiento, 2011, Retrieved from http://repositorio.cepal.org/ bitstream/handle/11362/3863/S2011000_es.pdf?sequence=1. 